\section{LATE NEOGENE DEFORMATION OF ROCK SUCCESSIONS AT RENAH GAJAH MATI I REGION, SELUMA REGENCY IN BENGKULU}

Wahidin Zuhri, Edy Sutriyono*

Geology Study Program, Faculty of Engineering, Sriwijaya University, South Sumatra, Indonesia
Article history

Received

14 January 2019

Received in revised form

19 December 2019

Accepted

16 January 2020

Published online

27 February 2020

${ }^{*}$ Corresponding author edy_sutriyono@yahoo.com

\section{Graphical abstract}

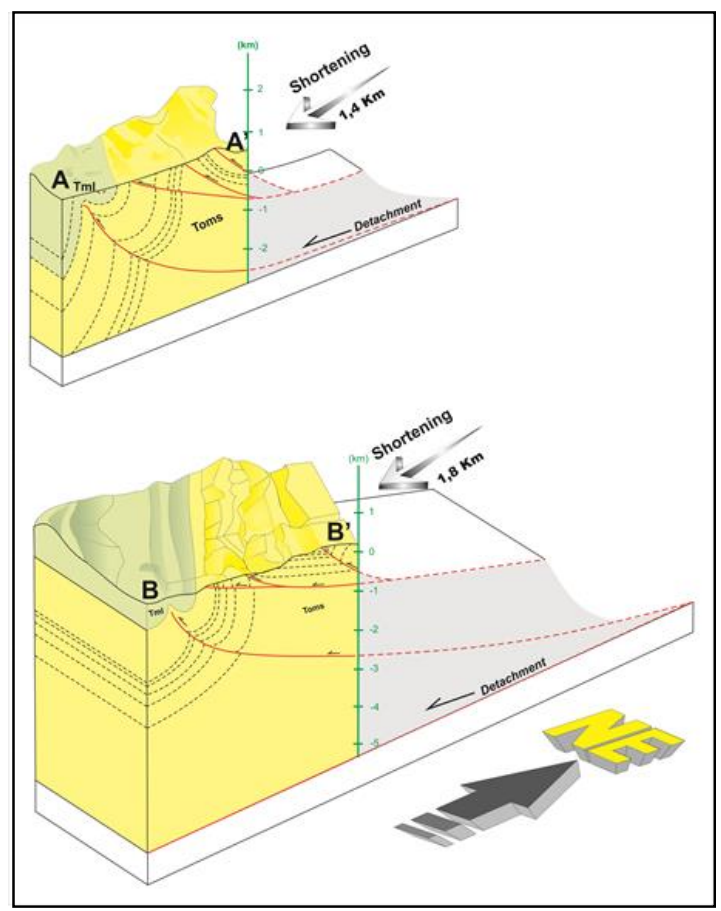

\section{Abstract}

Lack of work focusing on deformation mechanism has been undertaken in the Late Tertiary sequence during Late Neogene time at the Renah Gajah Mati I region in Bengkulu basin. The present study was aimed at reconstructing tectonic deformation occurring within the basin during the Late Neogene, employing balancing and restoring techniques, kinematic and dynamic analyses. The Late Neogene deformation was mainly controlled by compression, which has resulted in folding and thrusting. Hence, the rock sections underwent shortening that varied from $1.42-1.83 \mathrm{~km}$ or $0.75 \%-0.78 \%$ with the estimated rate of deformation $0.12-0.15 \mathrm{~mm} /$ year. Two types of tectonic structures developed within the region, fault propagation folds and trishear faults. The brittle deformation extended sequentially in the direction of tectonic transport, resulting in a series of faults. The generated faults constitute imbricate fans with a relatively closelyspaced thrust system. The array of thrusts is apparently associated with folds that strike NW-SE, implying the geometry of fault-linked folding. The hanging wall anticlines are generally asymmetric overturned folds, indicating a shallow ramping fault with a high shear pattern. In regional context, the general strike of structures within the study area appears relatively parallel to the NW-SE trending Barisan orogen. This feature suggests that tectonic transport responsible for structuring was likely at the NE- SW direction.

Keywords: Neogene deformation, folding, faulting, tectonic transport (C) 2020 Penerbit UTM Press. All rights reserved 


\subsection{INTRODUCTION}

The present study aims to reconstruct the deformational styles that involved the Late Tertiary sequence in the Renah Gajah Mati I (RGM I) region. The study area is located between latitude 4 ${ }^{\circ} 54^{\prime} 5^{\prime \prime}-$ $4^{\circ} 13^{\prime} 24.8^{\prime \prime} S$ and longitude $102^{\circ} 49^{\prime} 20.7^{\prime \prime}-102^{\circ} 54^{\prime} 14.4^{\prime \prime} E$. Particular areas from which observation and measurement for structural analysis were undertaken include the RGM I, Kemang Manis, Mekarsari Mukti, and Napalan districts of Seluma Regency, Bengkulu. The region is tectonically situated in the fore-arc setting of Bengkulu basin, and geologically constituted by the Tertiary rock units that have been deformed through folding and thrusting mechanism during Late Neogene time.

The basin has received liitle attention to studies on the development of tectonic deformation based on the outcropping structural elements. Indeed, the region has commonly been studied in terms of regional contexts, such as those conducted for instance by Gafoer et al. (1992) [1], Amin et al. (1993) [2], Yulihanto et al. (1995) [3] and Barber and Crow (2003) [4]. Hence, the current work may provide a package of scientific information containing a fundamental concept essential for better understanding on deformation mechanism within the basin. Such a concept is significant particularly in order to reconstruct the kinematic and dynamic processes involving sedimentary successions in the area during the Late Tertiary. In addition, results of the present study may to some extent provide important data that enable to reveal particular sites of a zone of weakness, in which fractures are existed in rock sequences. Thus, an attempt may be undertaken to identify more specific areas that are possibly susceptible to land deformation.

Figure 1 shows a geological map of the region. The study area comprises three lithostratigraphic units, from older to younger consecutively the Seblat Formation, the Lemau Formation, and the Quaternary Volcanic sequence. The lower succession consists mainly of sandstones intercalated with siltstones and mudstones, whilst the overlying Lemau column contains predominantly calcareous mudstones and fossiliferous mudstones. The youngest unit of rock section is constituted mainly by volcanic breccias and tuffs. The sedimentary sequence underwent tectonic compression that was coincident with the onset of Barisan orogeny in the Late Tertiary. The event allowed the formation of brittle structures in the Seblat unit, and ductile deformation in the Seblat and Lemau successions.

Regionally, the study area seems to have been controlled by the NW-SE trending alignments. This structural trend is consistent with the strike of Semangko Fault System occurring along the Barisan Mountain range. Importantly, tectonic events that have been responsible for structuring within the region and the surrounding area took place in the PlioPleistocene, coincident with the occurring Barisan orogeny (Pulunggono, 1992; Simanjuntak and Barber, 1996) $[5,6]$. Since the Late Neogene orogeny proceeded, the older tensional structures were reactivated by compressional regime. The later deformational system is considered to have regionally resulted in dextral movement along the Sumatran fault zone, and locally formed the NW-SE striking folds and thrusts (de Coster, 1974) [7]. Therefore, it is interpreted that the observed region has been subjected to extensional and subsequently compressive strains during the Tertiary. A particular interest of the present work is to analyze tectonic structures developed throughout the Seblat and Lemau successions for the selected sections, applying the techniques discussed in the following section.

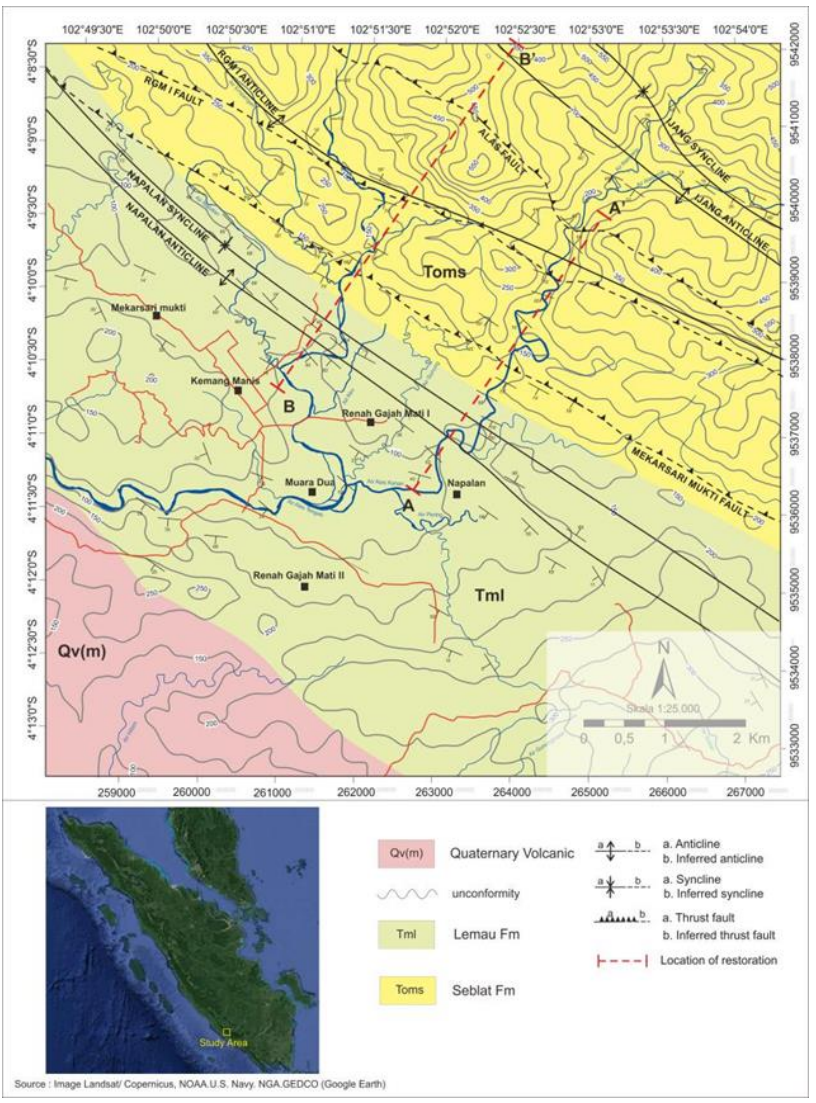

Figure 1 Geological Map of the study area. Also shown are cross section lines $A-A^{\prime}$ and $B-B^{\prime}$ for structural constructions discussed throughout the present paper

\subsection{METHODOLOGY}

This work conducted geological mapping by using a conventional ground survey in order to observe rock types and structures exposed throughout the study area. The outcropping rocks were described and mapped to generate the 1:25,000 scaled geological map. The identification and measurement of structural elements were carried out to construct the deformational styles occurred within the region. Structural studies herein have also adopted the 
geometrical evaluation of surface structures and a general interpretation of fault propagation folds (Mitra, 1990; McClay, 1992) [8, 9]. Moreover, structural analysis has applied the techniques of balancing and restoring sections crossing the $A-A^{\prime}$ and $B-B^{\prime}$ lines shown in Figure 1. The lines of sections were selected with consideration of the most available outcrop data. Interpretation of the deformational styles was supported by the 3D configuration of Digital Elevation Model (DEM) to gain regional features, in particular the alignments of topographic expression that may characterize structural controls. In modeling faultinteractive folding mechanism, this study employed the method suggested by Cardozo et al. (2003) [10]. Subsequently, the model was analyzed by utilizing "Stereo V8" program, especially in the determination of tectonic transport, whereas fault geometry was identified by the computer-aided "Fault Fold V6" software (Allmendinger, 2012) [11].

In the construction of balancing and restoring sections, two common methods are applied, the equal line-length and constant-area techniques. According to Dahlstrom (1969), there is no significant change in rock volume, and the initial thickness and length of the beds are maintained during tectonic deformation [12]. Therefore, this assumes that oblique shearing of sedimentary successions to bedding is negligible to the folding mechanism, thus the interpretation considers only the parallel folding of the beds. The area balancing method assumes that the rock volume remains equal during structuring episodes (Suppe and Medwedeff, 1990; Mosar and Suppe, 1992) $[13,14]$. Relying on this hypothesis, the creation of balanced section commonly applies area conservation, i.e. rock volume is conserved during deformation. Mitra and Namson (1989) distinguished the technique into the area restoration and the excess-area method [15]. However, the present study employed the excess-area approach in determining the depth to detachment and the regional shortening. Calculation of the depth to the detachment has been illustrated by Mitra and Namson, 1989; Dahlstrom, 1969, 1990) [15, 12, 16].

\subsection{RESULTS AND DISCUSSION}

Regional Late Neogene tectonic events allowed the development of ductile and brittle deformation throughout the study area. The brittle type apparently develops in competent layers of the Seblat sandstones, whereas the ductile structuring most likely forms the folding patterns in the Seblat and Lemau incompetent muddy sequences. Several structural elements such as overturned anticline, boudin, fold drag, and thrust fault are exposed in the region (Figure 2). The structures trend NW-SE at $\mathrm{N} 303^{\circ} \mathrm{E} / 72^{\circ}$ and $\mathrm{N} 301^{\circ} \mathrm{E} / 87^{\circ}$, and are parallel to the regional Barisan orogen striking along the western part of Sumatra. The anticlinal and synclinal features occur at the Napalan, ljang and RGM I region. The general orientation of the folds may determine the emergence of tectonic transport that has been responsible for deformation of rock sequence (Arslan, 2013) [17]. The measured limbs of the structures vary in dips between $4^{\circ}-79^{\circ}$, referred to as asymmetric overturned folds with the general hinge line oriented to the NW-SE direction by Leyson and Lisle, 1996 [18]. This implies that deformation of the region might have gradually progressed southwestwards, and it must have taken place in the Late Neogene, coincident with the inception of major tectonic events that allowed the building of Barisan Mountain range, which extends along the western portion of the island.

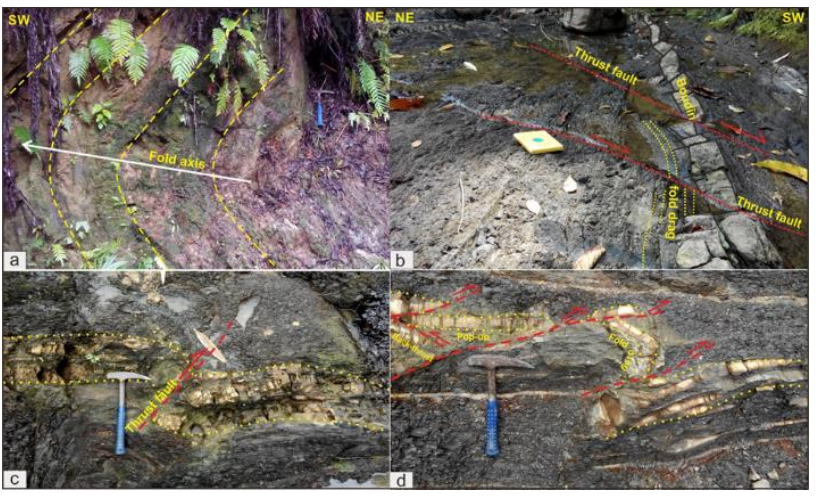

Figure 2 Structural elements outcropped in the region, a) overturned anticline, b) boudin and fold drag, c) thrust fault, and d) a series of low angle thrust faults, back-thrust, pop-up, and fold drag

There are three contractional fractures recognized in the region, namely the Alas, RGM I, and Mekarsari Mukti thrust faults that strike to the NW-SE direction. The faults might have elevated the upper sedimentary column. The Alas faults are exposed in the northern section of the Air Alas Kanan river, associated with fault drag oriented to the $N 308^{\circ} \mathrm{E} / 43^{\circ}$ direction. The RGM I thrust system occurs in the western segment of the river site, in which the fault breccias are exposed with the $\mathrm{N} 302^{\circ} \mathrm{E}$ measured strike. The fragmented rocks vary from 0.8 to $3 \mathrm{~cm}$ in diameter with the apparent thickness of about $56 \mathrm{~cm}$. This particular fractured zone is interpreted here as chaotic breccias (Woodcock and Mort, 2008) [19]. Besides, shear fractures (Peacock et al., 2018) [20]; are encountered in the region, showing cross-cutting geometry in the angle of $58^{\circ}-69^{\circ}$ with a general direction of approximately $\mathrm{N} 250^{\circ} \mathrm{E} / 66^{\circ}$ and $\mathrm{N} 12^{\circ} \mathrm{E} / 48^{\circ}$. The associated structure with the thrust fault is fold drag. Stereographic analysis results in the fault strike at $\mathrm{N} 302^{\circ} \mathrm{E}$, dipping to the $39^{\circ} \mathrm{NE}$ direction with a net slip $09^{\circ} \mathrm{N} 315^{\circ} \mathrm{E}$ and rake $16^{\circ}$. It is therefore interpreted as a thrust right slip fault (Rickard, 1972) [21]; with a maximum stress field $(\sigma 1)$ orientation $N 213^{\circ} \mathrm{E}$. The presence of Mekarsari Mukti thrust was observed at different localities along the Air Empangan river. Structural components exposed within the river sites included fault bedding $\mathrm{N} 294^{\circ} \mathrm{E} / 43^{\circ}$ and displacement of about $33 \mathrm{~cm}$, gouge, chaotic breccias, fault slip 
$\mathrm{N} 291^{\circ} \mathrm{E} / 22$ with rake $12^{\circ}$, and calcite veins oriented to the $\mathrm{N} 30^{\circ} \mathrm{E}$ strike. Overall, those thrust elements suggest a general fault strike of $\mathrm{N} 298^{\circ} \mathrm{E}$, hence tectonic transport responsible for thrusting was likely from northeasterly.

Two balanced and restored cross-sections along the A-A' and B-B' lines (Figure 3 and 4) have been constructed to interpret the structures of the region, which are thus geometrically admissible. Interpretations of ramp and flat systems adopted the fundamental concepts, which suggest that ramps occur commonly in competent rock layers, whereas flats develop better in less competent beds. Within the study area, the sandstones belonging to the Seblat sequence are interpreted to be the lower competent rocks, whilst the siltstones and mudstones of the Seblat Formation are likely to be the lower incompetent beds. The mudstones of the Lemau succession are referred to as the upper incompetent units. Additionally, brittle deformation is common in competent rocks, whereas ductile structuring likely develops within less competent rocks.

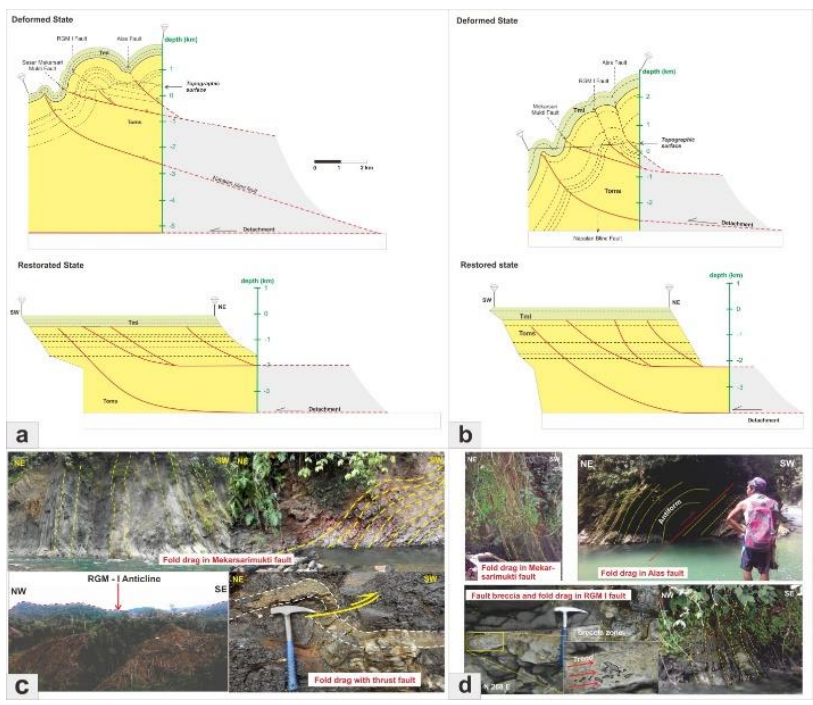

Figure 3 Composite models showing deformed and restored states crossing A-A' (a) and B-B' (b) lines. Shaded areas are to highlight interpretations of fault continuities at deeper levels. Also shown are the selected photographs of structural outcrops ( $c$ and d). See Figure 1 for location of cross sections

Table 1 displays the analytical results of calculation of depth to detachment and the amount of shortening for the region studied, and Figure 4 illustrates a simple technique used to calculate shortening of rock sequences along the A-A' and B-B' cross-sections followed the methods suggested by Mitra and Namson (1989); Dahlstrom (1969 and 1990) $[15,12,16]$
Table 1 Analytical results of depth to detachment and shortening estimates

\begin{tabular}{ccc}
\hline Sections & A-A' $^{\prime}$ & B-B' $^{\prime}$ \\
\hline $\mathrm{L}_{1}(\mathrm{~km})$ & 5.25 & 5.50 \\
$\mathrm{~L}_{0}(\mathrm{~km})$ & 6.67 & 7.38 \\
s (km) & 1.42 & 1.83 \\
contraction & 0.78 & 0.75 \\
ratio (\%) & 10.3 & 10.5 \\
A (km²) & 7.24 & 5.8 \\
Z (km) & 0.12 & 0.15 \\
$\mathrm{~V}(\mathrm{~mm} /$ years) & & \\
\hline
\end{tabular}

Where $L_{1}$ is deformed length, $L_{0}$ is initial length, $S$ is shortening, $A$ is area, $Z$ is depth of detachment, and $V$ is rate of deformation.

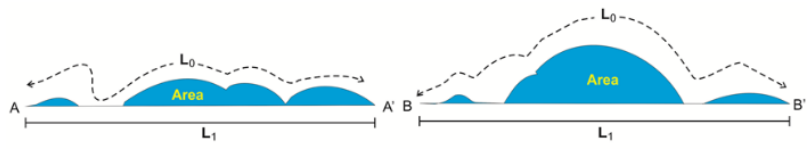

Figure 4 Illustration for calculation of depth to detachment using a simple formula $\mathrm{Z}=\mathrm{A} / \mathrm{LO}-\mathrm{L} \mathrm{l}$

Two structural models constructed in the present study show quite similar architectural styles. Both sections suggest that the region is characterized by fault-interacted folding features. The structures are observable particularly in the Early Miocene Seblat sequence and the Middle- Late Miocene Lemau succession. This phenomenon provides direct evidence that the rock units were tectonically deformed during the Plio-Pleistocene, concurrent with the uplift of the NW-SE trending Barisan orogen (Barber and Crow, 2003; Sieh et al., 2000) [4, 22]. Thrust faults developed principally in the Seblat rock unit, whereas folds appear existed in both Seblat and Lemau sequences. In addition, it is interpreted that the progression of fault tip lines might have led to folding, thus resulted in fault-propagation folds. The antiforms developed at the hanging walls commonly show an asymmetric overturned style. This indicates that the folding might have been controlled principally by a shallow ramp with a considerably high shearing during faulting. The interpretation is consistent with the structural models suggested by Cardozo, 2003; Corredor, 2005 [23, 24].

Table 1 describes that folding in the region permitted the shortening of rock sequence with the estimated minimum value ranging from $1.42 \mathrm{~km}$ to 1.83 $\mathrm{km}$, or a contraction ratio of $0.75 \%-0.78 \%$. In the construction, the calculated depths to detachment (Z) varied from $5.80 \mathrm{~km}$ to $7.24 \mathrm{~km}$, implying a shallow décollement along the lower incompetent beds within the Early Miocene Seblat Formation (Figure 5a). It is interpreted that the initiation of the incipient ljang fault was possibly in either the Late Miocene or the 
Early Pliocene. As compression progressed laterally, a flat developed, subsequently the tip line of fault to some extend went up to higher stratigraphic levels forming a ramp. Since the ramping proceeded, the rock cover folded and generated the hanging wall anticlines. As a result of this structuring, fault propagation folding developed in the entire Late Tertiary successions. Such deformation likely progressed southwestwards from backlimb to forelimb, and resulted in the trishear faults at the RGM I and Mekarsari Mukti areas. This scenario is consistent with the measured maximum strain at about $N 213^{\circ} \mathrm{E}$, suggesting tectonic transport to the NE-SW direction (Figure 6). Importantly, the fault propagation folding mechanism appears to have been responsible for the present topographic elevation within the presently investigated region. Additionally, a structural model showing mechanism deformation in the study area is presented in Figure 5b.

\subsection{CONCLUSION}

The present study reported in this manuscript draws some concluding remarks as the following. First, Late Neogene deformation has involved in the Late Tertiary sequence through thrusting and folding mechanism. Hence, the rock unit shortened tectonically between $1.42 \mathrm{~km}$ and $1.83 \mathrm{~km}$, or $0.75 \%$ and $0.78 \%$. Second, fault interacted folding appears to have resulted in fault propagation folds and trishear faults that developed in order from northeast to southwest in the Alas, RGM I, and Mekarsari Mukti areas. Third, the estimated rate of deformation may range from 0.12 to $1.15 \mathrm{~mm} /$ year with the NE-SW direction of tectonic transport. This interpretation is consistent with the PlioPleistocene compressive regime that has been responsible for the uplift of the Barisan Mountain range, which stretches NW-SE along the western portion of Sumatra.

\section{Acknowledgement}

This study is published with the permission of Head of Geology Study Program, Faculty of Engineering, University of Sriwijaya.

\section{References}

[1] Gafoer, S., Amin, T. C. and Pardede, R. 1992. Peta Geologi Lembar Bengkulu. Sumatra: Pusat Penelitian dan Pengembangan Geologi, Skala 1: 250.000, 1 Lembar

[2] Amin, T. C., Kusnama, Rustandi, E. \& Gafoer, S. 1993. Peta Geologi Lembar Manna \& Enggano, Sumatra: Pusat Penelitian dan Pengembangan Geologi, Skala 1: 250.000, 1 Lembar.

[3] Yulihanto, B., Siturnorang, B., Nunljajadi, A. and Sain, B., 1995. Structural Analysis of the Onshore Bengkulu Fore Arc Basin and Its Implication for Future Hydrocarbon Exploration Activity. Proceedings Indonesian Petroleum Association, 24 the Annual Convention. 85-96
[4] Barber, A. J., and Crow, M. J. 2003. An Evaluation of Plate Tectonic Models for the Development of Sumatra. Gondwana Research. 6(1): 1-28.

[5] Pulunggono, A., Haryo, S. A., and Christine, G. K. 1992. Pretertiary and Tertiary Fault Systems, as a Framework of the South Sumatra Basin: A Study of Sar Maps. Proceedings $21^{\text {st }}$ Annual Convention, IPA. 338-360.

[6] Simanjuntak, T. O. and Barber, A. J. 1996. Contrasting Tectonic Styles in the Neogene Orogenic Belts of Indonesia. In R. Hall and D. J. Blundell, (ed.). Tectonic Evolution of Southeast Asia. Geological Society Special Publication, London. 185-201.

[7] De Coster, G. L. 1974. The geology of the central and south Sumatra basin. Proceedings $3^{\text {rd }}$ Annual Convention, IPA. 77-110.

[8] Mitra, S. 1990. Fault-propagation Folds: Geometry, Kinematic Evolution, and Hydrocarbon Traps. American Association of Petroleum Geologists Bulletin. 74: 921-94.

[9] McClay, K. R. 1992. Glosarry of Thrust Tectonic Terms. In K. R. McClay (ed). Thrust Tectonics. Chapman and Hall. 419-433.

[10] Cardozo, N., Bawa-Bhalla, K., Zehnder, A. T., and Allmendinger, R. W. 2003. Mechanical Models of Fault Propagation Folds and Comparison to the Trishear Kinematic Model. Journal of Structural Geology. 25(1): 1-18.

[11] Allmendinger, R. W. 2012. Manual Fault Fold Forward v.6, Geological Society of America Abstracts with Programs. 119.

[12] Dahlstrom, C. D. A. 1969. Balanced Cross Sections. Canadian Journal of Earth Sciences. 6: 743-757.

[13] Suppe, J. and Medwedeff, D. 1990. Geometry and Kinematics of Fault-propagation Folding. Eclogae Geologicae Helvetiae. 83(3): 409-454.

[14] Mosar, J. and Suppe, J. 1992. Role of Shear in Faultpropagation Folding. K. R. McClay (ed.). Thrust Tectonics. Chapman and Hall, London. 123-132.

[15] Mitra, S. and Namson, L. 1989. Equal-area Balancing. American Journal of Science. 89: 563-599.

[16] Dahlstrom, C. D. A. 1990. Geometric Constraints Derived from the Law of Conservation of Volume and Applied to Evolutionary Models for Detachment Folding. Am. Assoc. Pet. Geol. Bull. 74: 336-344.

[17] Arslan, A., Güngör, T., Erdogan, B., and Passchier, C. W. 2013. Tectonic Transport Directions of the Lycian Nappes in Southwest Turkey Constrained by Kinematic Indicators. Journal of Asian Earth Sciences. 64: 198-209. DOI :http://dx.doi.org/10.1016/j.jseaes.2012.12.016.

[18] Leyshon, R. L. and Lisle, R.J. 1996. Stereographic Projection Techniques in Structural Geology. British Library Cataloguing in Publication Data, UK.

[19] Woodcock, N. H. and Mort, K. 2008. Classification of Fault Breccias and Related Fault Rocks. Geol. Mag. Cambridge University, UK, Press. 145: 435-440 DOI: 10.1017 /S0016756808004883

[20] Peacock, D. C. P., Sanderson, D. J., and Rotevaten, A. 2018 Relationships between Fractures. Journal of Structural Geology. 106: 41-53. DOI :https://doi.org/10.1016/j.jsg.2017. 11.010.

[21] Rickard, M. J. 1972. Fault Classification-Discussion. Geological Society of America Bulletin. 83: 2545-2546.

[22] Sieh, K. and Natawidjaja, D. 2000. Neotectonics of the Sumatran Fault, Indonesia. J. Geophys. Res. 105. 295-326.

[23] Cardozo, N., Bawa-Bhalla, K., Zehnder, A. T., and Allmendinger, R. W. 2003. Mechanical Models of Fault propagation Folds and Comparison to the Trishear Kinematic Model. Journal of Structural Geology. 25(1): 1-18.

[24] Corredor, F., Shaw, J. H., and Bilotti, F. 2005. Structural Styles in the Deep-water Fold and Thrust Belts of the Niger Delta. AAPG Bulletin. 89(6): 753-780. DOI: $10.1306 / 02170504074$. 

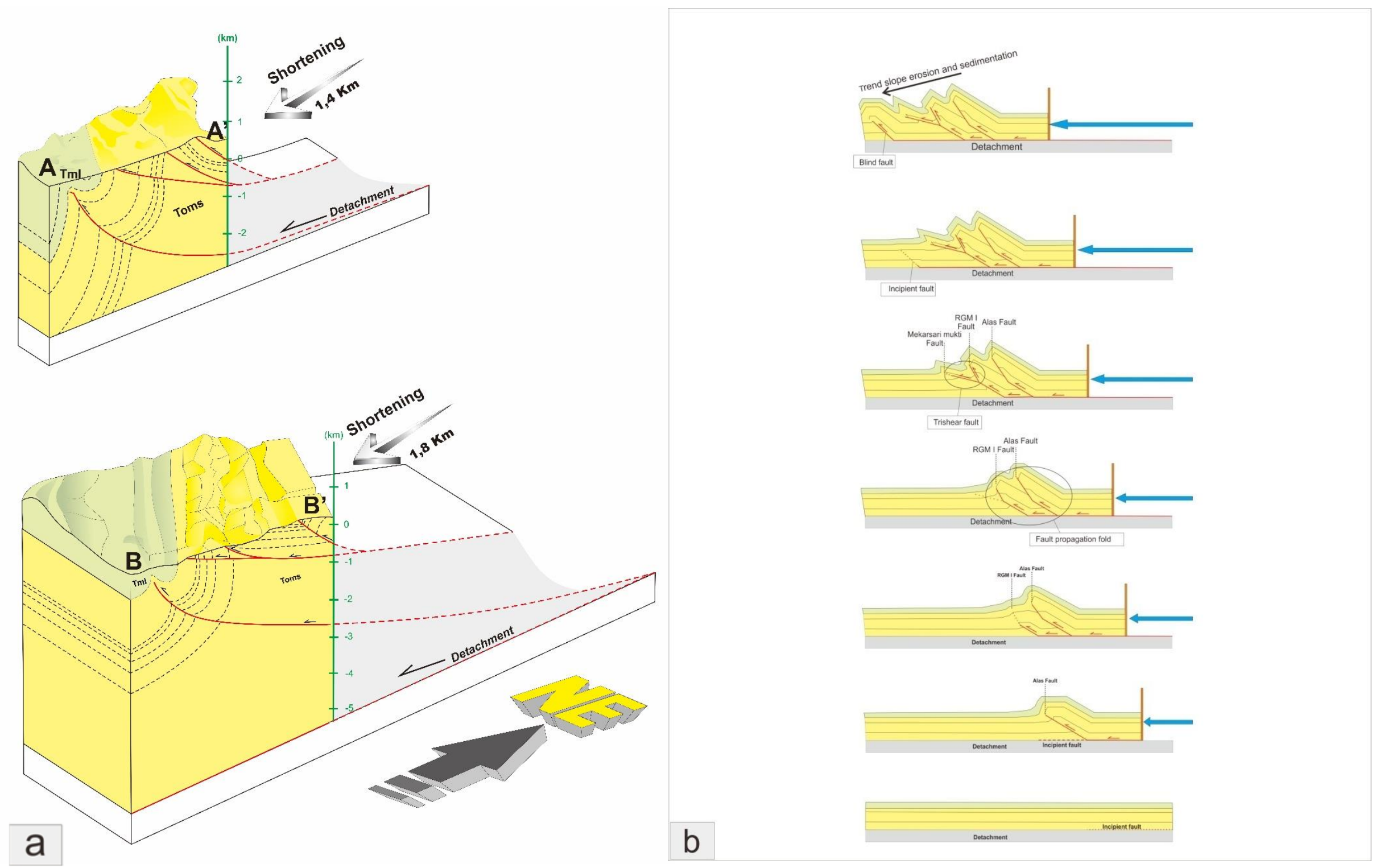

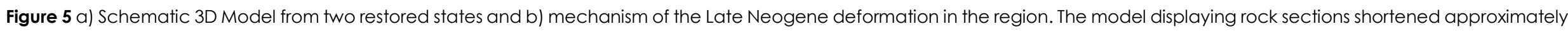
$0,8 \%$ 


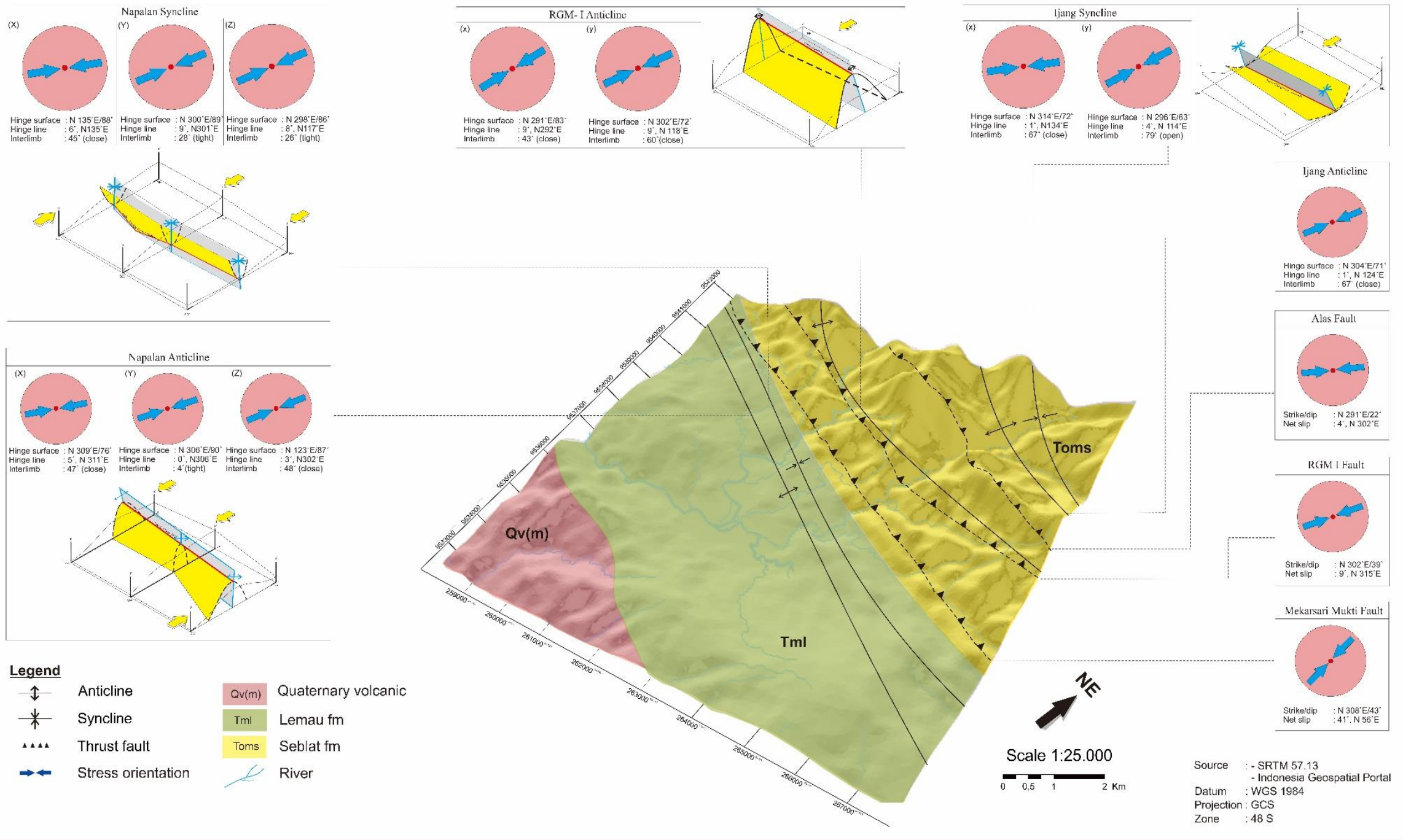

Figure 6 The Interpreted stres orientation of folds and faults in study area. Also shown is the corresponding geological map 